DOI: $10.31866 / 2410-1915.20 .2019 .172428$

УДК 304(73:510)

\title{
КИТАЙСЬКА ТА АМЕРИКАНСЬКА МРІЯ З КУЛЬТУРНОЇ ПЕРСПЕКТИВИ: ПОРІВНЯЛЬНИЙ АНАЛІЗ
}

\author{
Маслова Анастасія Олександрівна
}

Магістр міжнародних відносин,

ORCID:0000-0002-0014-3592,17210170456@fudan.edu.cn, Університет Фудань,

Хенден Шосе, 220, Шанхай, Китай, 200433

У статті аналізується китайська та американська мрії і прослідковується різниця між ідеальними соціальними потребами Китаю і США. Мета статті полягає у визначенні подібного та відмінного між «китайською мрією» і «американською мрією» у сприйнятті теоретичних і академічних наукових кіл. Саме тому дослідження концептів китайської та американської мрії $є$ актуальним та має значну наукову цінність.

Основними методологічними принципами у дослідженні стали аналіз та порівняння, які дозволили визначити ключові параметри для здійснення оцінки та відбір чинників, що впливають на міжкультурну взаємодію та співробітництво, холізм та індивідуалізм «китайської мрії» 3 «американською мрією».

Крім того, застосовано метод історизму для розгляду первинних форм «китайської мрії» та «американської мрії» та за допомогою якого можна прослідкувати різницю між ідеальними соціальними потребами Китаю і США.

Висновки. Доведено, що оригінальна форма «китайської мрії» 3 найдавніших часів походить від вимог ідеального суспільства в Китаї та має більш світський характер. Джерелом «американської мрії» була «східна мрія» та пуританський реформаторський рух в просуванні американських політичних і соціальних реформ.

«Американська мрія» базується на індивідуалістичних цінностях таких як особисте процвітання, що проявляється в особистих досягненнях, сімейному щасті та матеріальному благополуччі. Реалізація «американської мрії» відбувається у таких факторах як політична система, економічне середовище, культурна толерантність тощо. А на основі природних прав на свободу, рівність і братерство, американці особливо виокремили право на пошуки щастя.

«Китайська мрія» більше виявляється в омолодженні китайської нації, процвітанні та могутності країни тощо, вона більш всеосяжна, тоді як «американська мрія» є здебільшого реалістичною і матеріальною.

Ключові слова: «китайська мрія»; «американська мрія»; культура; суспільство; гармонія.

\section{Вступ}

Значний відгук суспільства отримала ідея «китайської мрії», запропонована китайським президентом Сi Цзіньпіном у 2012 р.

(C) Маслова А. О., 2019 
Компаративний аналіз понять «китайської мрії» та «американської мрії» також став темою гарячих дискусій. Порівняльний аналіз «китайської мрії» у територіально найбільших країнах, що розвиваються, і «американської мрії» у найбільш розвинених державах, відіграє ключову роль у політичному, економічному та соціальному векторах розвитку інших країн. Саме тому, дослідження концептів китайської та американської мрії $є$ актуальним та має значну наукову цінність.

3 огляду на значну кількість досягнень та недоліків на терені порівняльного аналізу «китайської та американської мрій», виникає нагальна потреба у продовженні наукових пошуків.

Сьогодні існує значна кількість наукових досліджень щодо концептів «китайської та американської мрії», особливо на території Китаю. Окреслюючи подібність «китайської мрії» 3 «американською мрією», все ж китайські вчені переважно акцентують увагу на спільному ідеалі, справедливості, демократії та цивілізації від прагнення до щастя, національної культури, політичних позицій та перспектив розвитку. Наприклад, в роботі Чжоу Сіаньсінь «Особливості американської мрії та її вплив на китайську мрію» обгрунтована ідея про необхідність поважати реалістичну конотацію «американської мрії», особливо в аспектах інноваційного духу, особистої цінності та сприяння соціальної рівності (Zhou and Haо, 2013) Важливо підкреслити м'яку силу культури і будівельну логіку, яку описує в книзі Ма Шенга «Логіка побудови американської мрії i ïï вплив на китайську мрію», що допомагає підвищити національну довіру до «китайської мрії», особливо у побудові справедливого, демократичного, цивілізованого і гармонійного суспільного середовища, перенести позитивне значення «американської мрії» (Zheng and Kong and Lu, 2008). Аналізуючи ці дві національні мрії, у своїй роботі Чжу Джидун «У чому полягає відмінність між «китайською» та «американською мрією»?» пояснив особливості попереднього підгрунтя, конотації, цінності, способі реалізації і перспективи двох мрій (Yue, 2007). У своїй роботі Чжао Лей і Сінь Яо «Китайська та Американська мрія» орієнтувалися на ідеологічну основу, тип, істотні характеристики, історичну еволюцію і політичну спрямованість мрій (Zhou and Нао, 2013). Чень Сяньян і Чень Цзіньян «Чітке кредо китайської та американської мрій» пояснюють передумови, терміни, шляхи реалізації та стратегічні відносини із зарубіжними країнами (Zheng, Kong and Lu, 2008).

\section{Мета статті}

Мета статті полягає у визначенні подібного та відмінного між «китайською мрією» і «американською мрією» у сприйнятті теоретичних i академічних наукових кіл. Дана розвідка сприяютиме також роз'ясненню неправильних уявлень щодо зв’язку між цими двома концептами.

Основними методологічними принципами у дослідженні стали аналіз та порівняння, які дозволили визначити ключові параметри для здійснення оцінки та відбір чинників, що впливають на міжкультурну взаємодію та співробітництво, холізм та індивідуалізм «китайської мрії» 
3 «американською мрією». Крім того, застосовано метод історизму для розгляду первинних форм «китайської мрії» та «американської мрії» та за допомогою якого можна прослідкувати різницю між ідеальними соціальними потребами Китаю і США.

\section{Виклад основного матеріалу}

Аналізуючи уявлення про «китайську мрію» та «американську мрію» виокремимо такі аспекти цих концептів:

1. Міжкультурна взаємодія та співробітництво

«Китайська мрія»є важливою ланкою керівної ідеології і концепції правління, запропонованою президентом Сi Цзіньпіном. Основним змістом цього принципу є «реалізація великого омолодження китайської нації» (Xi, 2013, с. 10). Проте активні міжнародні відосини сприяли більш тісному зв’язку для розвитку Китаю з іншими країнами. Досвід втілення китайської реформи відкритості протягом сорока років свідчить про важливість концепту «відкриття», через реалізацію стратегії «залучення» $\mathrm{i}$ «виходу» та політику «Одного поясу, одного шляху» (Xi, 2013, p. 11). Режим співпраці Китаю передбачає не тільки все більш широке і поглиблене співробітництво $з$ рештою світу, але й відповідальність за сприяння спільному розвитку і процвітанню світу. 3 цієї точки зору «китайська мрія» має світове значення не тільки тому, що ії̈ реалізація вимагає різних форм взаємодії та співпраці міжнародного співтовариства, а також тому, що вона сприятиме розвитку всіх країн світу.

«Американська мрія» $\epsilon$ найбільш далекосяжною складовою «національної мрії» і має стійкий, глобальний вплив, тобто «незалежно від походження, американці покладаються на свої власні здібності й досягнення, мають можливість мати краще життя» (Zhou and Hao, 2013, р. 15). «Національна мрія» за своєю сутністю $є$ «національною», оскільки не включає «іноземців» в межах країни. Це була рання форма «американської мрії». А коли вона здобула певну практичну реалізацію, наприклад, отримання американцями земель, тоді вона стала приваблювати тогочасних європейців. 3 розвитком глобалізації стало практично неможливо, щоб так звана «національна мрія» мала тільки національні форму й зміст.

2. Первинні форми «китайської мрії» та «американської мрї̈»

Оригінальна форма «китайської мрії» 3 найдавніших часів походить від вимог ідеального суспільства в Китаї. Прикладом $є$ вирішення проблеми продовольства і одягу, процвітання життя, гармонії сімейних i соціальних відносин тощо. Двома типовими моделями ідеального суспільства стародавнього Китаю були мрії Лаоздзи про «малу країну 3 малочисельним населенням» і мрія Конфуція про «велику гармонію» (Zheng, Kong and $\mathrm{Lu}, 2008$, c. 1592). «Збирання хризантеми під східною огорожею і неквапливе споглядання краєвидів гори Неншан» $є$ типовим ідеальним суспільством в уявленні Лаодзи про «малу країну із нечисельним населенням», що передбачає відчуття вільності від гніту світу і повернення 
до природи (Zheng, Kong and Lu, 2008, с. 1594). Даоській школі, яку він представляє, властивий сильний ідеал «натуралізму». На сучасному етапі 3 процвітанням культу охорони навколишнього середовища і зеленої природи ідеальне суспільство даосизму особливо бажане. Воно, в уявленні Конфуція, має тривалий і глибокий вплив у Китаї. Значною мірою уявлення Конфуція про життя і мрію великої гармонії більш конкретні, тобто «дорога - це також подорож, світ публічний» (Toynbee, 2010, с. 801). Ідеальне суспільство конфуціанства, представлене Конфуцієм і Мендзи, не тільки більш конкретне, але й містить благородніші моральні та духовні прагнення, які можуть бути поза досяжністю багатьох ідеальних суспільств. Мрія конфуціанства все ще має ряд кроків або етапів для реалізації. Основними рушіями ідеального суспільства в Стародавньому Китаї були характер, знання, саморозвиток, сімейна єдність, управління країною і світом, мир. Конфуційська система, сто років тому описана у відомому китайському філософському трактаті під назвою «Книга про Велике Єднання», де за допомогою останніх спостережень і аналізу сучасного Західного світу узагальнене бачення ідеального суспільства, конфуціанських традицій, аби увесь «світ» перебував у гармонії (Kang, 2005, p. 117). Важливо зазначити, що у ній навіть розглядалося питання про соціальну інтеграцію темношкірого населення .

Джерелом «американської мрії» $є$ «східна мрія», тобто мета Колумба знайти новий шлях на Схід, щоб отримати золото, спеції та інші багатства Сходу (як відомо, ним став Новий Світ Америки). Хоча це і $є$ прагнення до «східної мрії» для європейців, вона також має дуже сильне релігійне значення для північноамериканських колоній (Fogel, 2000, p. 6). У 1630 р. пуритани Англії приплили до Північної Америки з великими втратами, 3 думкою, що Бог призначив їм зустріч, щоб подарувати Новий Світ. Їхня пустельна місія, і насправді релігійна місія, полягала у тому, щоб виконати обіцянку перед Богом і будувати Новий Світ «на вершині гори», який має бути взірцем для усього світу. Хоча їхня практика побудови пуританської теократії - єдності політики і релігії, врешті-решт зазнала невдачі, пуританська місія у Північній Америці мала глибокий вплив на американське суспільство. Відомий американський економіст Фогель у книзі «Четверте велике пробудження і майбутнє рівності» детально викладає важливу роль пуританського реформаторського руху в просуванні американських політичних і соціальних реформ (Fogel, 2000, p. 2). Прикладами є звільнення рабів, рух за права жінок та прогресивність, які уособлювали глибокий пуританський релігійний дух.

Таким чином, китайці приділяли велике значення своїм моральним досягненням з давніх часів, шляхом підкреслення верховенства літератури над господарюванням, сім’єю та природою. «Американська мрія» спочатку мала релігійну місію і в основному проявлялася в гонитві за матеріальними багатствами, виступаючи за свободу і незалежність, довіряючи природі.

3. Холізм і індивідуалізм «китайської мрї̈» та «американської мрії»

«Американська мрія» базується на індивідуалістичних цінностях. Значною мірою, це мрія про особисте благополуччя, або навіть мрія 
про особисте процвітання. «Американська мрія» сучасних американців в основному проявляється в особистих досягненнях, сімейному щасті й матеріальному благополуччі. Реалізація американської мрії відбувається в таких галузях, як політична система, економічне середовище, культурна толерантність тощо. Декларація про незалежність Джефферсона вперше виявила ідеальну і реалістичну основу американської мрії: «Ми віримо, що такі істини є очевидними: всі люди народжуються рівними, а творець дарує людям ряд невід'ємних переданих прав, включаючи право на життя, право на свободу і право шукати щастя» (Armitage, 2007). На основі природних прав на свободу, рівність і братерство, американці особливо виокремили право на пошуки щастя. Глибокий вплив «американської мрії» полягає в тому, що американці всі тісно пов'язані з «американською мрією». Насправді, більш ніж через 200 років історичного розвитку, чарівність «американської мрії» полягає в іiі вільному, відкритому й толерантному політичному та соціальному середовищі. Однак розвиток «американської мрії» поступово переходив у крайнощі. Практично всі американські політики зауважують, що вони з бідних верств і надбали усі здобутки в житті завдяки важкій праці. Незважаючи на те, що Сполучені Штати поширюють у світі позитивні образи влади, багатства, свободи і справедливості, чи є це реальністю в самих штатах? За змінами нинішньої ситуації в Сполучених Штатах Америки за пів століття 3 моменту перебування в політиці, аналізу реальних справ американської держави під час виборчої кампанії, Берні Сандерс, американський політик-ветеран, написав статтю «Наша революція» про занепад олігархії та демократії в США. Ця стаття відображає інституційну дилему та соціальну кризу відступу, занепокоєння середнього класу, розрив між багатими та бідними, податкові питання, виховне навантаження, найважливіше покарання, вразливі групи та маніпулювання 3MI. «Для багатьох американців американська мрія - жахіття», - заявив він у своїй виборчій кампанії 2016 p. (Sanders and Ruffalo 2016).

«Китайська мрія» більше виявляється в омолодженні китайської нації, процвітанні й силі країни тощо. Навіть якщо це пов'язано з особистим рівнем, це також $\epsilon$ проявом «народного щастя». Оскільки розвиток західного суспільства був відносно зрілим, Китай зараз займається «наздоганяючим» модернізаційним будівництвом, більш специфічна стандартизація ідеалів і цілей дійсно є типовою практикою країн, що розвиваються. Західне суспільство має глибоко вкорінену традицію індивідуалізму, яка стверджує, що особиста цінність є вищою за соціальну цінність (Yue, 2007, р. 159). Американці говорять про «американську мрію», а не про «спільне процвітання». Насправді, мрії західного світу, представлені «американською мрією», в основному втілюються у побудові інститутів у політичній, економічній та соціальній сферах, закладаючи тим самим інституційну та політичну основу для досягнення рівності можливостей i навіть більш широкого соціального перерозподілу (Yue, 2007, p. 164). Наприклад, Європа сприймає загальну мету державного добробуту як ефективну підтримку свого ідеального суспільства. 
4. Взаємодія між «китайською мрією» $i$ «американською мрією»

Варто зазначити, що різниця між «китайською мрією» i «американською мрією» полягає, в основному, в чотирьох аспектах. Поперше, «китайська мрія» має більш тривалу історію. Хоча «американська мрія» продовжує прагнення до ідеального суспільства в західному світі, тривалість існування західної цивілізації значно менша ніж китайської цивілізації. По-друге, «китайська мрія» має більш світський характер. Багато людей можуть сказати, що китайці не мають релігійної стриманості, але вони також досягають гарної соціальної інтеграції за відсутності релігійних норм і норм віросповідання. По-третє, «китайська мрія» має більш очевидну особливість холізму. Четвертим параметром $\epsilon$ те, що «китайська мрія» більш всеосяжна, а «американська мрія» переважно $\epsilon$ реалістичною і матеріальною. Традиційний твір «Китайський Сон» $є$ яскравим прикладом, який надає великого значення ідеалам духовного і морального рівня (Liu, 200, p. 87). Автор вважає, що саме тут східна мрія перевершує західну мрію.

Чи це Китай чи Сполучені Штати, чи офіційні, чи неурядові, економічні та торговельні обміни або політична взаємна довіра, необхідно реалізовувати основні поняття та принципи дій щодо поваги до культурних відмінностей, шукати спільну мову, зберігаючи відмінності, та спільний розвиток задля розбудови системи вдалого культурного обміну між двома країнами і досягнення соціального «виграшу». Лише за рахунок розширення економічних і культурних обмінів, а також усунення непорозумінь і неоднозначностей може бути здійснена взаємодія між урядами і суспільствами двох країн.

\section{Висновки}

Доведено, що оригінальна форма «китайської мрії» 3 найдавніших часів походить від вимог ідеального суспільства в Китаї та має переважно світський характер. Джерелом «американської мрії» була «східна мрія» та пуританський реформаторський рух в просуванні американських політичних і соціальних реформ.

«Американська мрія» базується на індивідуалістичних цінностях таких як особисте процвітання, що проявляється в особистих досягненнях, сімейному щасті та матеріальному благополуччі. Реалізація американської мрії відбувається таких факторах, як політична система, економічне середовище, культурна толерантність тощо. А на основі природних прав на свободу, рівність і братерство, американці особливо виокремили право на пошуки щастя.

«Китайська мрія» переважно виявляється в омолодженні китайської нації, процвітанні та могутності країни тощо, вона більш всеосяжна, тоді як «американська мрія» переважно реалістична і матеріальна. 


\section{Список використаних джерел}

1. Armitage D. The Declaration of Independence: A Global History. Cambridge, Mass ; London : Harvard University Press, 2007. 300 p.

2. Fogel R.W. The Fourth Great Awakening and the Future of Egalitarianism. University of Chicago Press, 2000. 383 p.

3. 康有 「. 大同「. 上海：上海古籍出版社, 2005. 117頁.

4. 「「. 文化身「「跨文化「播. 北京: 外「「刊, 2000. 數 1. 頁.87-91.

5. 阿「德·「因比. 「史「究. 上海：上海人民出版社, 2010, 頁.801-802.

6. Sanders B., Ruffalo M. Our Revolution: A Future to Believe In. Barnes \& Noble. New York : Macmillan Audio ; Prince Frederick, MD, 2016 p. 213 p.

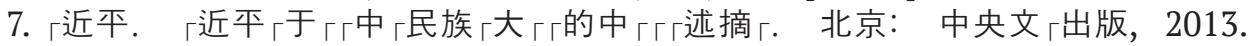
頁. 10-12.

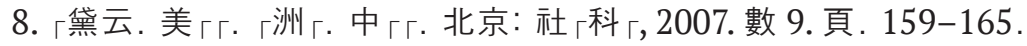

9. 「玄. 孔「「，「友仁. 「「正「. 上海：上海古籍出版社上海, 2008. 頁. 1592-1595.

10. 周 $「$ 信. 卡浩瑄. 美 $「\lceil$ 的特色及其 $「$ 中 $「$ 的 $「$ 示. 北京：探索, 2013. 數 2. 頁. 15-19.

\section{References}

Armitage, D. (2007). The Declaration of Independence: A Global History. Cambridge, Mass; London: Harvard University Press.

Fogel, R.W. (2000). The Fourth Great Awakening and the Future of Egalitarianism. University of Chicago Press.

Kang, Y. (2005). Book of Great Harmony. Shanghai Guji Chubanshe.

Liu, S. (2000). Cultural Identity and Cross-cultural Communication, no. 1, pp. 87-91.

Toynbee, A. (2010). Historical Studies, pp. 801-802.

Sanders, B. and Ruffalo, M. (2016). Our Revolution: A Future to Believe in. Barnes \& Noble. New York : Macmillan Audio ; Prince Frederick, MD.

Xi, Jinping. (2013). Selected Compilations of Xi Jinping's Discourse on Realizing the Chinese Dream of the Great Rejuvenation of the Chinese Nation, pp. 10-12.

Yue, D. (2007). American Dream. European dream. Chinese dream, no. 9, pp. 159-165. Zheng, X., Kong, Y. and Lu, Y.(2008). Book of Rights. Shanghai: Shanghai Guji Chubanshe, pp. 1592-1595.

Zhou, X. and Hao, H. (2013). The Characteristics of the American Dream and Its Enlightenment to the Chinese Dream, no. 2, pp. 15-19. 


\title{
THE CHINESE AND AMERICAN DREAMS FROM THE CULTURAL PERSPECTIVE: COMPARATIVE ANALYSIS
}

\author{
Anastasiia Maslova
}

\author{
$M A$ in International Relations, \\ ORCID:0000-0002-0014-3592,17210170456@fudan.edu.cn, \\ Fudan University, \\ Shanghai, China
}

The article analyzes the Chinese and American dreams and traces the difference between the ideal social needs of China and the United States of America. The aim of the article is to define a similar and distinct the "Chinese dream" and the "American dream" in the perception of the theoretical and scientific community. That is why the study of the concepts of the Chinese and American dreams is relevant and of considerable scientific value.

The main methodological principles of the research are the analysis and comparison, which allowed determining the key parameters for the evaluation and selection of factors influencing intercultural interaction and cooperation, holism and individualism of the "Chinese dream" with the "American dream".

In addition, the historicism method was applied to consider the primary forms of the "Chinese dream" and the "American dream" and with which you can provide insight into the difference between the ideal social needs of China and the United States.

Conclusions. It is proved that the original form of the "Chinese dream" has come from China ideal society`s requirements and had a more secular character since the earliest times. The source of the "American dreams" was the "Eastern dream" and a puritan reform movement to promote American political and social reforms.

The "American Dream" is based on individualistic values such as personal prosperity, which appears via personal achievements, family happiness and material well-being. The "American dream" journey begins with political system, economic environment, cultural tolerance, etc. Moreover, on the basis of the intrinsic rights to liberty, equality and fraternity, Americans have specifically identified the right to the pursuit of happiness.

The "Chinese dream" is more expressed in the rejuvenation of the Chinese nation, the prosperity and power of the country, etc., it is more comprehensive, while the "American dream" is mostly realistic and material.

Keywords: "Chinese Dream"; “American Dream”; culture; society; harmony. 


\section{КИТАЙСКАЯ И АМЕРИКАНСКАЯ МЕЧТА С КУЛЬТУРНОЙ ПЕРСПЕКТИВОЙ: СРАВНИТЕЛЬНЫЙ АНАЛИЗ}

\section{Маслова Анастасия Александровна}

Магистр международных отношений, ORCID:0000-0002-0014-3592,17210170456@fudan.edu.cn, Университет Фудань, Шанхай, Kитай

В статье анализируется китайская мечта и американская мечта. Прослеживается разница между идеальными социальными потребностями Китая и США. Цель статьи заключается в определении подобного и различного между «китайской мечтой» и «американской мечтой» в восприятии теоретических и академических научных кругов. Именно поэтому исследование концептов китайской и американской мечты является актуальным и имеет значительную научную ценность.

Основными методологическими принципами в исследовании стали анализ и сравнение, которые позволили определить ключевые параметры для оценки и отбор факторов, влияющих на межкультурное взаимодействие и сотрудничество, холизм и индивидуализм «китайской мечты» с «американской мечтой».

Кроме того, применен метод историзма для рассмотрения первичных форм «китайской мечты» и «американской мечты» и с помощью которого можно проследить разницу между идеальными социальными потребностями Китая и США.

Выводы. Доказано, что оригинальная форма «китайской мечты» с древнейших времен происходит от требований идеального общества в Китае и имеет более светский характер. Источником «американской мечты» была «восточная мечта» и пуританское реформаторское движение в продвижении американских политических и социальных реформ.

«Американская мечта» базируется на индивидуалистических ценностях как личное процветание, что проявляется в личных достижениях, семейном счастье и материальном благополучии. Реализация «американской мечты» происходит в таких факторах как политическая система, экономическая среда, культурная толерантность и тому подобное. А на основе природных прав на свободу, равенство и братство, американцы особенно выделили право на поиски счастья.

«Китайская мечта» больше проявляется в омоложении китайской нации, процветании и могуществе страны и т.д., она более всеобъемлющая, тогда как «американская мечта» является частью реалистичной и материальной.

Ключевые слова: «китайская мечта»; «американская мечта»; культура; общество; гармония. 